\title{
Factors of the brand image influencing students' choices in higher education institutions in Ho Chi Minh City
}

\author{
Hoang Thi Que Huong ${ }^{1 *}$, Tran Tien Khoa ${ }^{2}$ \\ ${ }^{1}$ University of Economics and Law, VNU-HCM, Vietnam \\ ${ }^{2} \mathrm{Ho}$ Chi Minh City International University, VNU-HCM, Vietnam \\ *Corresponding author: huonghtq@uel.edu.vn
}

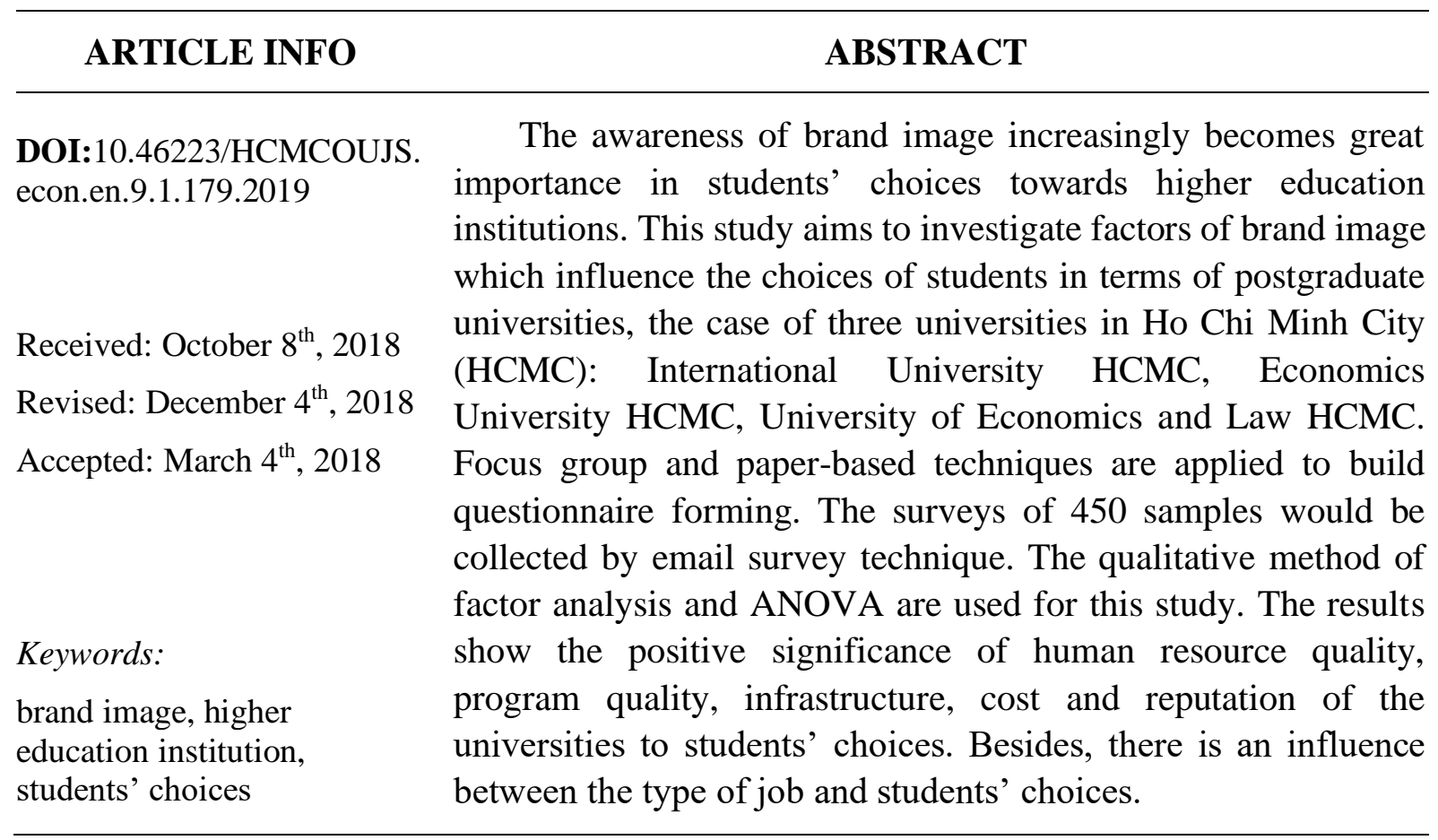

\section{Introduction}

In the context of integration with the world economy, the affirmation and enhancing the position of the country become a general trend of all countries, especially developing countries. Moreover, education in Vietnam currently plays a very important role not only for students and parents but also for teachers and lecturers in order to create useful people for society's development. In particular, higher education has an essential thing in creating and increasing the value of the national brand. In an increasing competition in higher education, institutions have to face the huge challenges in the high caliber students and academic staff. The awareness of students about the brand of the institution may have influences on the success of institutions and students' intentions to engage with the university in the future. The fact that nowadays more and more students would like to study higher education programs in domestic not only in programs of English taught but also in Vietnamese. Understanding the demand of the market, there are many studies related to brand management for universities which attract more students. Almost studies are related to how to build and develop brand name for universities in general and there is a lack of research about higher education program which linked to the brand 
image of universities. Thus, this study will investigate the factors of image influencing students' choices in higher programs.

The first objective is to investigate the factors of brand image that influence choices of students in term of higher education in these universities: International University HCMC, University of Economics and Law and the University of Economics. The second objective is to examine the relationship between these factors and find out the most influenced factors of the brand image toward students' choices. The third objective is to study the influence of demographic variables on students' choices towards higher education institutions.

\section{Literature review}

\subsection{Higher education}

According to UNESCO (1998) the definition of higher education can be illustrated as follows:

Higher education comprises all post-secondary education, training and research guidance at educational institutions such as universities that are authorized as institutions of higher education by state authorities.

In the Vietnam educational system, higher education is for people who completed the study at universities. In other words, people who have a bachelor's degree can apply for higher education programi.es in terms of related fields.

\subsection{Brand and brand management}

Many authors have definitions of brand and according to Kotler a brand is defined as "a name, term, sign, symbol, or design, or a combination of them, intended to identify the goods and services of one seller or a group of sellers and to differentiate them from those of competitors" (Kotler, 1997, p. 443). According to Heding, Knudtzen, and Bjerre (2009, p. 9) they stated that the definition of the brand can be in some more aspects which included internal and organizational processes.

Kapferer $(2012$, p. 7) stated that brand management starts with the product and service as the prime vector of perceived value, while communication is there to structure, to orient tangible perceptions and to add intangibles ones. Another understanding of brand management which is mentioned in Management Study Guide (n.d.) is the management of tangible and intangible characteristics of the brand.

\subsection{Brand approach}

According to Heding et al. (2009) there are seven main brand approaches that need to be considered and divided into two paradigms which are positivistic and constructivist. These seven brand approaches are illustrated through three periods of time which are human/receiver focus, company/sender focus and cultural/ context focus. These seven brand approaches are 
named as the economic approach, the identity approach, the personality approach, the consumer-based approach and the relational approach.

In the economic approach, the transaction theory and marketing mix theory are applied to analyze the economic brand. The main method of the economic approach is a quantitative method using in order to investigate the relationship between variables of management of marketing mix and consumer choices in terms of brand. From that the author found out how these variables affect consumer choices. For the implication of the economic approach, the Four Ps are very famous and important for brand manager to plan a brand strategy for a company.

In the identity approach, four primary supporting themes related to brand identity are mentioned and they are corporate identity, organizational identity, brand image. There are two aspects that are illustrated in the identical approach and they are internal and external sides. On the internal side, corporate identity and organizational identity are mentioned. However, for the external side, the brand image elements are considered analyzing through cognitive and social psychology methods. This identity approach can be applied to improve the brand identity for organizations through many actions related to brand image, reputation, behavior and culture of organizations.

The personality approach is applied through the concepts of the cognitive consumer perspective and theory of a process of information in terms of consumer choices. Moreover customer-based brand equity is taken into account for this approach.

According to Heding et al. (2009) the personality approach assumes that personality traits are important drivers for analysis between brand and consumer. There are three supporting themes in the personality approach. They are personality, consumer self and brand-self congruence.

In the relational approach, three theories are applied to analyze brand management and they are animism, human relationships and brand relationship. (Heding et al., 2009). The author emphasizes the method of depth interviews and life story used to research relationships.

In the community approach, there are three primary theories that have been used include community theory, subcultures of consumption and brand community. Many methods are ethnographic methods and ethnography methods used to research brand communities. (Heding et al., 2009).

In the cultural approach, the theory of cultural branding, the No Logo movement and its resistance to branding and the theory of the citizen-artist brand prospect are three main theories. Variety methods that have been used to research cultural consumption include macro-level analysis and micro-level data. (Heding et al., 2009).

The seven brand approaches can be summarized by the table as follows: 


\section{Table 1}

The seven brand approaches

Two paradigms

\begin{tabular}{ll}
\hline & $\begin{array}{l}\text { Human/ } \\
\text { receiver focus }\end{array}$ \\
Positivistic & Company/ \\
sender focus
\end{tabular}

Constructivist
The economic approach

The identity approach

The personality approach

The consumer-based approach

The relational approach

Cultural/

context focus The community approach

The cultural approach

Source: Heding et al. (2009).

\subsection{Brand image}

Bhasin (2013) stated that brand image is a deciding factor that directly affects the sales of products. Moreover, he mentioned that brand image is an accumulation of beliefs and views about that particular brand. The value and characters of the brand portrayed by their image and this is the main component in the scheme of things. One of the essentials is the brand image that is the mirror that reflects the organization's key values. Some organization which has a range of good quality products but has a bad evaluation of brand image may lead to a decrease in sales and profits as well. Therefore, the brand image is one of the important factors that influence companies' successes and long-term strategies.

Many researchers have studied brand image and the definition of brand image can be summarized by the following table: 


\section{Table 2}

Brand image concept in the brand literature

\begin{tabular}{|c|c|c|}
\hline Perspective & Source & Definition of brand image \\
\hline \multirow{3}{*}{$\begin{array}{l}\text { Blanket } \\
\text { definitions }\end{array}$} & Herzog (1963) & $\begin{array}{l}\text { Consumers 'general perception and impression of a } \\
\text { brand }\end{array}$ \\
\hline & $\begin{array}{l}\text { Newman } \\
(1985)\end{array}$ & $\begin{array}{l}\text { Consumers 'perception of a product's total } \\
\text { attributes }\end{array}$ \\
\hline & Dichter (1985) & $\begin{array}{l}\text { Consumers 'general impression of the product or } \\
\text { service }\end{array}$ \\
\hline \multirow{3}{*}{$\begin{array}{l}\text { Meanings and } \\
\text { messages }\end{array}$} & Noth (1988) & $\begin{array}{l}\text { The symbolic meaning embedded in the product or } \\
\text { service }\end{array}$ \\
\hline & $\begin{array}{l}\text { Sommers } \\
\text { (1964) }\end{array}$ & $\begin{array}{l}\text { Consumers 'perception and recognition of a } \\
\text { product's symbolic attribute }\end{array}$ \\
\hline & Levy (1973) & $\begin{array}{l}\text { The symbolic meaning of purchasing the product or } \\
\text { service }\end{array}$ \\
\hline \multirow{3}{*}{ Personification } & $\begin{array}{l}\text { Martineau } \\
(1957)\end{array}$ & $\begin{array}{l}\text { Brand image reflects consumers 'characteristics, } \\
\text { and they purchase the brand to express themselves }\end{array}$ \\
\hline & $\begin{array}{l}\text { Bettinger } \\
(1979)\end{array}$ & $\begin{array}{l}\text { The personification of a product, which can be } \\
\text { manifested as "adult" and "children" }\end{array}$ \\
\hline & Sirgy (1985) & Image of the brand resembles human personality \\
\hline \multirow{4}{*}{$\begin{array}{l}\text { Cognitive or } \\
\text { psychological } \\
\text { elements }\end{array}$} & $\begin{array}{l}\text { Gardner \& } \\
\text { Levy (1955) }\end{array}$ & $\begin{array}{l}\text { Brand image is consisted of consumers 'opinion, } \\
\text { attitude and emotion toward a brand, which reflects } \\
\text { the cognitive or psychological elements of the brand }\end{array}$ \\
\hline & Levy (1978) & $\begin{array}{l}\text { Consumers 'overall impression about a brand or } \\
\text { product, which includes recognition, feeling and } \\
\text { attitude toward it }\end{array}$ \\
\hline & $\begin{array}{l}\text { Bullmore } \\
(1984)\end{array}$ & $\begin{array}{l}\text { Consumers' general perception and opinion of a } \\
\text { brand's total attributes }\end{array}$ \\
\hline & $\begin{array}{l}\text { Kapferer } \\
\text { (1994) }\end{array}$ & $\begin{array}{l}\text { Consumers' general perception about the brand } \\
\text { feature's association }\end{array}$ \\
\hline
\end{tabular}

Source: Zhang (2015).

\subsection{Relationship between factors of brand image and students' choices}

To understand the importance of brand image this study tries to illustrate all indicators that influence students' choices in higher education institutions and the case is conducted in three HCM city universities.

According to Keller (2013, p. 72), he stated that:

Creating brand awareness by increasing the familiarity of the brand through repeated exposure (for brand recognition) and forging strong associations with the appropriate product category or other relevant purchase or consumption cues (for brand recall) is an important first step in building brand equity. Once a sufficient level of brand awareness is created, marketers can put more emphasis on crafting a brand image. 
The brand image has been studied for a long time and it is proved that this is an important concept in marketing. Brand image is considered that this is related to the consistent with associative network memory model which mentions consumer perceptions of a brand. The brand image reflects consumer memory by the brand associations. In other words, information of brand association links to brand memory of consumers and this has meaning to consumers. Associations may come from characteristics of the product or any related aspects of the product. (Keller, 2013, p. 79).

The corporate image will depend on many dimensions as follows:

Common product, attributes, benefits or attitudes there are two dimensions that contribute noticeably to a strong association of brand image and they are of high quality and innovation. (Keller, 2013, p. 411). High quality for higher education programs may come from many aspects such as the quality of human resources, the quality of program structures, the infrastructure of the universities. It is clear that the quality program related to all courses and contents which satisfy students' expectations. Le (2012) suggested that all these above dimensions have a positive effect on the brand image of Saigon University. Moreover, attribute dimensions of the corporate image which bring positive associations of the brand image is the cost of the program. The second dimension is about innovation which can be considered in order to create strong associations of brand image. Keller (2013, p. 412) stated that perceived innovativeness is also a key competitive weapon and priority for firms in other countries According Nhat Hong (2017) she emphasized that innovation in training methods, service quality and management contribute significantly to the brand of the university.

People and relationships: according to Keller (2013, p. 412) these elements are related to the professional of employees and service quality in order to bring the best quality product to consumers. A customer-focused corporate image association creates consumer perceptions of a company as responsive to and caring about its customers (Keller, 2013, p. 412). Thus, the professional of human resources in a university plays a primary role in the creation of a strong association of brand image to students' memory in order to increase students' choices.

Value and program: Keller (2013, p. 413) stated that these dimensions are related to social responsibility. A socially responsible corporate image association portrays the company as contributing to community programs, supporting artistic and social activities, and generally attempting to improve the welfare of society as a whole.

According to Le (2012) stated that the reputation of a university has a positive effect on the brand image of a university. Moreover, Enache (2011) also mentioned that the importance of reputation in modern educational institutes. Universities are more and more orient to develop and keep a good reputation. 


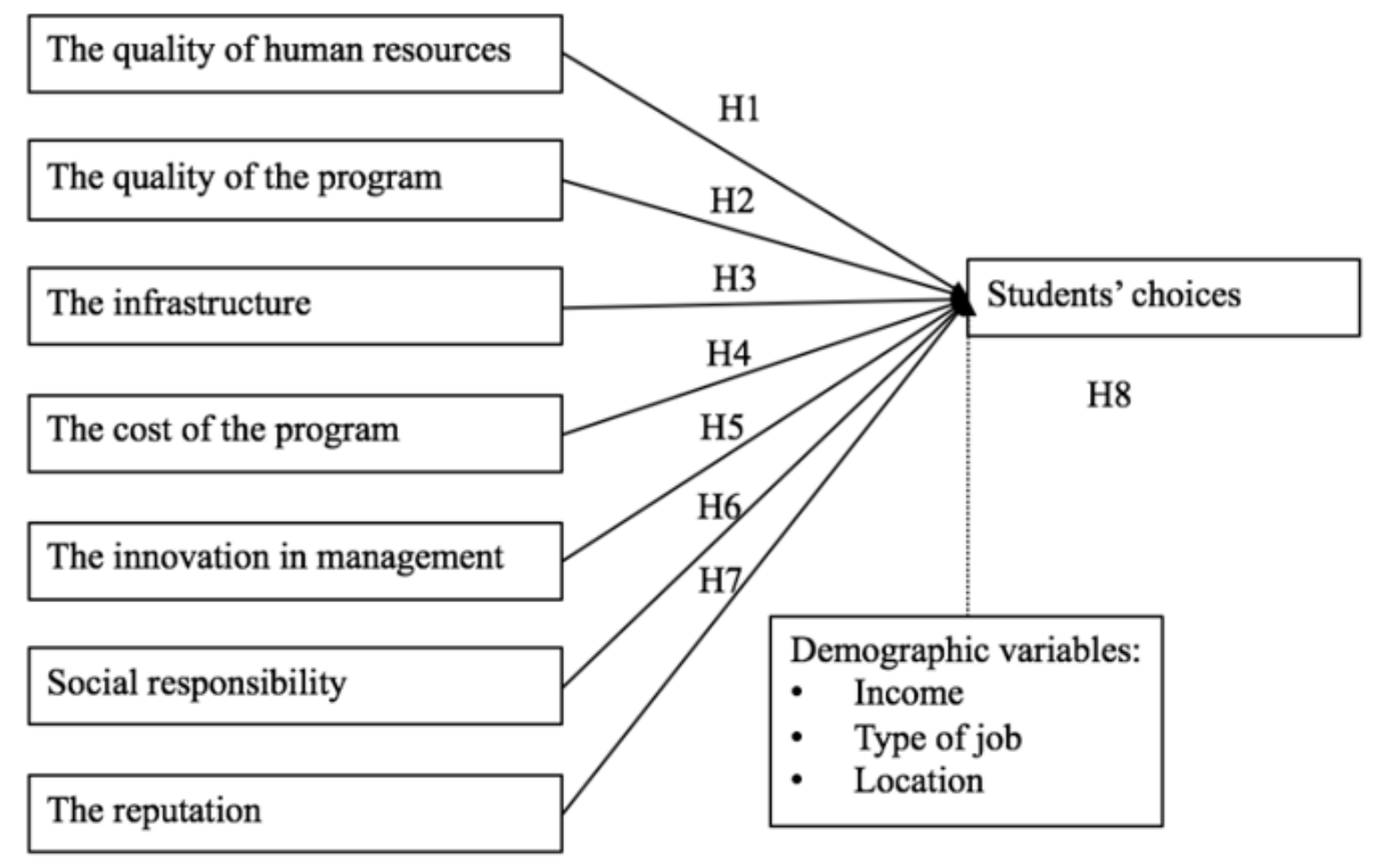

Figure 1. Theoretical framework

The concept of reputation is used in order to influence students' choices when selecting higher education institutions. Understanding a reputation concept enables management to use it more effectively in communication strategy which has a major role in the positioning of an institution (Nguyen \& LeBlanc, 2001, p. 303). Those with whom the institutions have the need to communicate. On the one hand, those from internal surroundings such as present students, faculty staff, but on the other, recruiters and potential applicants. It is relevant to say that all these subjects from internal and external environments interact with each other, thus, consistency is here particularly important. The message which is created for the public can be in the form of publications, press releases, speeches, memos, reports and the variety of other channels which schools use to interact with their constituencies.

There are numerous benefits of having a good reputation for the higher education market. For instance, a favorable reputation on foreign markets can be beneficial in two ways. On the one hand, it is institutions' interests that attract talented foreign students, but on the other hand, by attracting foreign students and enjoying good reputation abroad the institution will reinforce the idea that the educational programs are of high quality, internationally oriented, acknowledged and appreciated outside the country borders. Additionally, a good reputation among employees will distinguish higher education institutions, resulting in greater respect on the part of the employers, consequently increasing the recruitment prospects of candidates from this higher education institution rather than from other institutions (Martensen \& Grønholdt, 2005). 
There are many studies that prove the influences of demographic variables on decision making related to choices of education institutions. According to College Board (2005) they stated that changing in demographic modified students' choices in many kinds of institutions. Students may orient to apply to community colleges because there is a low cost of tuition fees and a development of course work possibility.

\section{Research methodology}

\subsection{Hypothesis development}

Based on the above discussion the following relationship between students' choices and brand image of the universities is hypothesized:

H1: The quality of human resource of the university is positive and direct to students' choices towards higher education institutions

H2: The quality of the program is positive to students' choices towards higher education institutions.

H3: The infrastructure of the university is positive to students' choices towards higher education institutions

H4: The cost of the program is positive to students' choices towards higher education institutions

H5: The innovation in management and training methods are positive to students' choices toward higher education institutions

H6: Social responsibility of the university is positive to students' choices towards higher education institutions

H7: Reputation of the university is positive to students' choices towards higher education institutions

H8a: Location influences to students' choices towards higher education institutions

H8b: Income influences to students' choices towards higher education institutions

H8c: Type of job influences to students' choices towards higher education institutions

\subsection{Research design}

Chapman (1981) proposed the first model in which six points are used to measure all the items related to factors influencing students 'choices in colleges. Recently many researchers adapted the 5-points Likert scales to measure factors affecting students "choice in higher education institutions. Wiese, Heerden and Jordaan (2010) adapted Likert scales to measure the role of demographic variables in the selection of students in higher education institutions. This study will apply 5-point Likert scales for all items' measurements. The scales which are range from 1 to 5 and they mean strongly disagree, disagree, neither agree nor disagree, agree, 
strongly agree with respect to $1,2,3,4,5$. If a student chooses scales of 1 , it describes the student strongly disagrees with the item.

The questionnaire is illustrated in two sections. Section 1 describes the students' information about demographic variables such as the name of the university, name of higher education program, gender, age, type of job, monthly income, location. Section 2 presents the evaluation of all factors influencing students' choices in higher education institutions.

After the qualitative research, the questionnaire is formed. The study consists of 46 independent variables and 3 dependent variables. According to Green (1991) he stated two important reasons for multiple regression and statistical power and the sample size should be illustrated by the formula as follows:

$\mathrm{N}>50+8 \mathrm{~K}$, where $\mathrm{K}$ is the number of independent variables

Thus, the sample is required:

$\mathrm{N}>50+8 * 46=418$

Therefore, the final sample size should have a minimum number of 450 .

The survey will be delivered to three universities in Ho Chi Minh City as mentioned above. All respondents must study in higher education programs. The proportion of survey of three universities is around equal, with around 33\%. The questionnaires were delivered to the students by email by the end of August 2017. An email survey was created by Google and sent out to students by email. Students answered the questionnaire by filling in the email survey and the responses were collected. As a result, there are 450 samples from the email survey and these samples will be used for data analysis.

\subsection{Data analysis method}

Data analysis method is based on a process of quantitative analysis. It means the results of data analysis will be clear figures. These numbers will be showed in terms of tables, charts, or percentages. Data manipulating will be done by statistical techniques. For this study, the IBM SPSS version 22 will be used for all analyses. This process of analysis will be carried out step by step as following.

First of all, excel software and spreadsheets are applied to enter the raw data from the questionnaire. The items will be sorted and grouped in reasonable order and it will help the following process of data analysis more easily.

Next, SPSS software is used as an intermediate means of analysis. Data will be input into spreadsheets of the SPSS window. Here, data will also be coded according to the purpose of research: the chosen 'strongly disagree, disagree, neither agree nor disagree, agree, strongly agree' are converted to corresponding numbers 1,2,3,4 or 5. This data will be saved and used for the process of analysis later. 
Cronbach's Alpha testing will help to check the reliability of the survey results. The threshold of Cronbach's Alpha for all constructs to verify is greater than 0.6. If the construct has Cronbach's Alpha less than 0.6, some belonging items will be deleted to conform to.

The exploratory factor analysis (EFA) needs to be carried out in order to confirm all variables creating their factors.

At the next stage, the multiple regression will be analyzed to find out the relationship between independent variables and dependent variables.

Finally, ANOVA analysis is conducted to find out the relationship between demographic variables and choices of students. The quality of human resources was divided into six measurement items, the quality of the program was divided into five measurement items, the infrastructure into four measurement items, the cost of the program into six measurement items, the innovations into management into five measurement items, the social responsibility into five measurement items, the reputation into five measurement items and the students' choices into three measurement items.

\section{Results and Discussion}

\subsection{Reliability analysis}

The checking of reliability of all factors is satisfied if the values are higher than 0.6. With the elimination of variables c19 $(\mathrm{a}<0.6)$, the Cronbach's alpha of all factors is satisfied. Variable c19 which means "Lecturers ensure a peaceful environment in class" is eliminated from the factor of the study environment.

\section{Table 3}

Factors and Cronbach's Alpha

\begin{tabular}{|c|c|c|c|}
\hline Factor & Code & Items & $\begin{array}{l}\text { Cronback's } \\
\text { Alpha }\end{array}$ \\
\hline \multirow{5}{*}{$\begin{array}{c}1 \\
\text { Lecturer } \\
\text { Quality }\end{array}$} & $\mathrm{c} 1$ & $\begin{array}{l}\text { Professors are highly qualified in dealing with the } \\
\text { students }\end{array}$ & \multirow{5}{*}{0.869} \\
\hline & $\mathrm{c} 2$ & $\begin{array}{l}\text { Professors have in-depth knowledge of the subject } \\
\text { matter }\end{array}$ & \\
\hline & $\mathrm{c} 3$ & Lecturers' methods of evaluating students are fair & \\
\hline & $\mathrm{c} 4$ & $\begin{array}{l}\text { Professors' teaching method encourages students to } \\
\text { develop self-determination and activeness in learning }\end{array}$ & \\
\hline & c6 & $\begin{array}{l}\text { Professors are experienced enough to satisfy } \\
\text { students' specialty needs }\end{array}$ & \\
\hline \multirow{2}{*}{$\begin{array}{l}2 \\
\text { Employee }\end{array}$} & c7 & $\begin{array}{l}\text { University employees treat to all with no } \\
\text { discrimination }\end{array}$ & \multirow[b]{2}{*}{0.915} \\
\hline & $\mathrm{c} 8$ & $\begin{array}{l}\text { University employees help the students in terms of } \\
\text { needs }\end{array}$ & \\
\hline
\end{tabular}




\begin{tabular}{|c|c|c|c|}
\hline Factor & Code & Items & $\begin{array}{c}\text { Cronback's } \\
\text { Alpha }\end{array}$ \\
\hline & c9 & $\begin{array}{l}\text { The communication of the employees to students is } \\
\text { good }\end{array}$ & \\
\hline & $\mathrm{c} 10$ & $\begin{array}{l}\text { The support staffs are helpful, caring and easily } \\
\text { accessible to students }\end{array}$ & \\
\hline & $\mathrm{c} 11$ & All the inquiries are dealt speedily, effectively & \\
\hline & $\mathrm{c} 12$ & $\begin{array}{l}\text { Function departments efficiency coped with } \\
\text { complaints from student }\end{array}$ & \\
\hline \multirow{5}{*}{$\begin{array}{l}3 \\
\text { Program } \\
\text { Quality }\end{array}$} & $\mathrm{c} 13$ & Variety of courses meet your expectations & \multirow{5}{*}{0.877} \\
\hline & $\mathrm{c} 14$ & $\begin{array}{l}\text { The program makes me satisfied and it can fulfill the } \\
\text { gap between theory and practice }\end{array}$ & \\
\hline & $\mathrm{c} 15$ & $\begin{array}{l}\text { Workshops and conferences are very useful in terms } \\
\text { of courses understanding }\end{array}$ & \\
\hline & $\mathrm{c} 16$ & The content of the required subjects meets my needs & \\
\hline & $\mathrm{c} 17$ & Educational material meets your expectations & \\
\hline \multirow{4}{*}{$\begin{array}{l}\quad 4 \\
\text { Study } \\
\text { Facilities }\end{array}$} & $\mathrm{c} 22$ & $\begin{array}{l}\text { Classrooms are arranged properly and they are } \\
\text { adequately ventilated and safe }\end{array}$ & \multirow{4}{*}{0.859} \\
\hline & $\mathrm{c} 23$ & $\begin{array}{l}\text { The equipment (computers, projectors, etc.) for } \\
\text { teaching and learning are of high quality }\end{array}$ & \\
\hline & $\mathrm{c} 24$ & $\begin{array}{l}\text { The supporting information systems (mail, website, } \\
\text { blackboard, etc.) are effective for student and } \\
\text { lecturer interaction }\end{array}$ & \\
\hline & $\mathrm{c} 25$ & $\begin{array}{l}\text { Library had a modern electronic system and opening } \\
\text { hours are available }\end{array}$ & \\
\hline \multirow{7}{*}{$\begin{array}{c}5 \\
\text { Cost }\end{array}$} & $\mathrm{c} 26$ & The tuition fees are affordable & \multirow{7}{*}{0.891} \\
\hline & $\mathrm{c} 27$ & The tuition fees are equal to your willingness to pay & \\
\hline & $\mathrm{c} 28$ & The tuition fees enough to ensure program quality & \\
\hline & c29 & I feel satisfied with the tuition fees of the program & \\
\hline & $\mathrm{c} 30$ & I am willing to pay extra for better programs & \\
\hline & $\mathrm{c} 31$ & $\begin{array}{l}\text { The tuition fees are entirely related to the quality } \\
\text { program }\end{array}$ & \\
\hline & $\mathrm{c} 38$ & The university commits truthful information & \\
\hline 6 & $\mathrm{c} 18$ & $\begin{array}{l}\text { The financial services (such as scholarships, loans) } \\
\text { are comprehensive and diverse }\end{array}$ & 0.872 \\
\hline
\end{tabular}




\begin{tabular}{|c|c|c|c|}
\hline Factor & Code & Items & $\begin{array}{l}\text { Cronback's } \\
\text { Alpha }\end{array}$ \\
\hline \multirow{5}{*}{$\begin{array}{l}\text { Social } \\
\text { Responsibil } \\
\text { ity }\end{array}$} & c33 & Extracurricular programs are diversity, attracting & \\
\hline & $\mathrm{c} 34$ & Many practical activities are related to the courses & \\
\hline & $\mathrm{c} 40$ & The university has volunteer activities for students & \\
\hline & $\mathrm{c} 41$ & $\begin{array}{l}\text { There is a social dialogue between university and } \\
\text { government and enterprises }\end{array}$ & \\
\hline & $\mathrm{c} 46$ & $\begin{array}{l}\text { The university is distinguished by the competitive } \\
\text { advantages such as graduates' state of being } \\
\text { employed or promoted }\end{array}$ & \\
\hline $\begin{array}{c}7 \\
\text { Reputation }\end{array}$ & c42 & $\begin{array}{l}\text { University reputation provides you with } \\
\text { encouragement to enroll }\end{array}$ & 0.885 \\
\hline
\end{tabular}

Source: The researcher's data analysis

\subsection{Demographic profile}

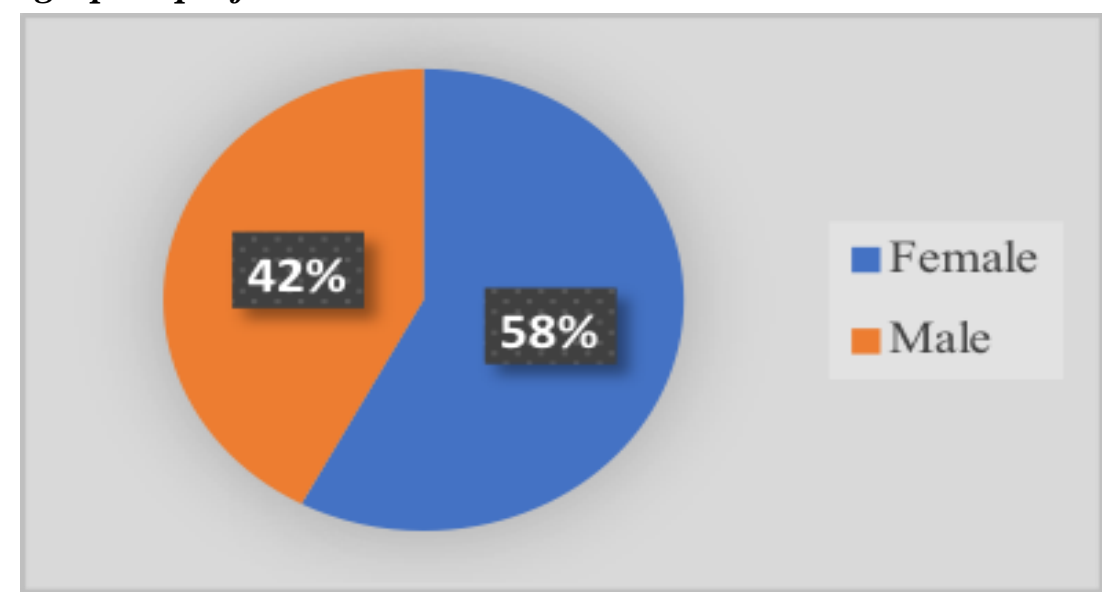

Figure 2. Gender

Regarding the gender, the sample covers 450 including 260 female students which account for $57.8 \%$ and 190 male students for $42.2 \%$. 


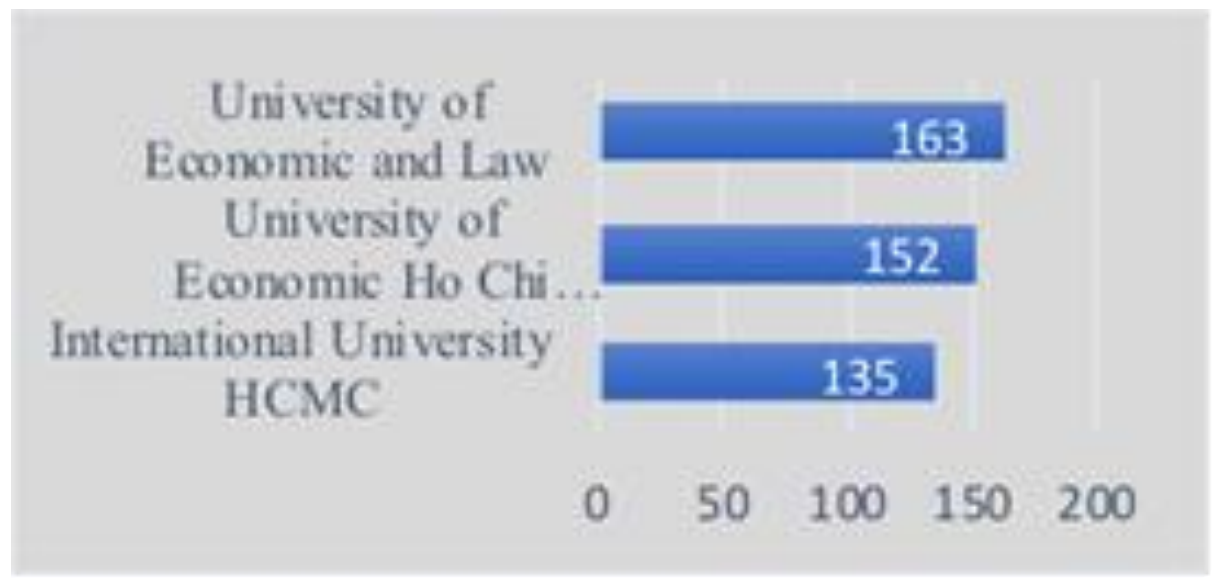

Figure 3. Universities

The total sample consists of 30\% of HCMC International University, 33.8\% of HCMC University of Economics and 36.2\% of HCMC University of Economics and Law. Regarding the higher programs, the most percentage of higher programs is business administration, with 201 students and $44.7 \%$. Finance programs attract 116 students with $25.8 \%$. Besides, the higher program of international business and economics hold the third and fourth proportions of the sample.

In terms of age, the majority of respondents belong to the $22-27$ age group with 270 students and $60 \%$. The second group from 28 - 33 years of age with 127 students and $60 \%$. The other group from 34 - 39 years of age with 45 students and $10 \%$.

With respect to marital status, from the above-mentioned age group of 22-27, a huge proportion of the respondents (333 students with 74\%) was single. Besides, the number of married respondents was nearly half the singles (117 ones and 26\%).

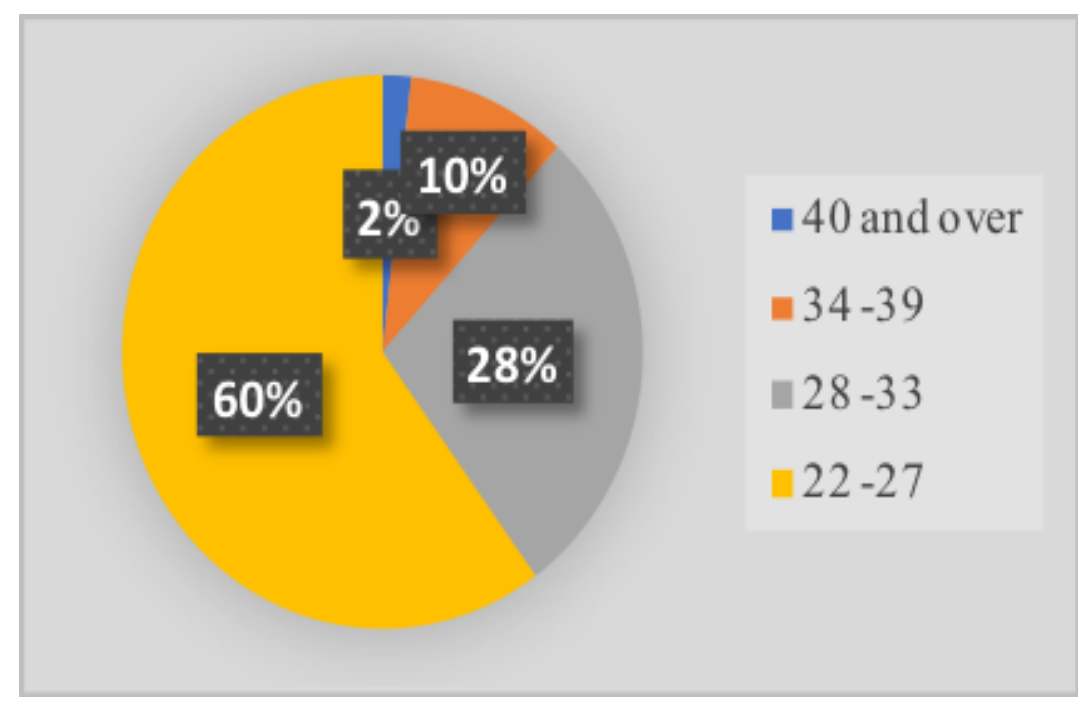

Figure 4. Age

Most of the students which are holding the position of office staff are studying higher programs (318 students and 70.7\%). Furthermore, 65 students hold the management position 
(14.4\%), and self-employed with 30 students (6.7\%). Besides, 29 lecturers are studying higher programs, which account for $6.4 \%$.

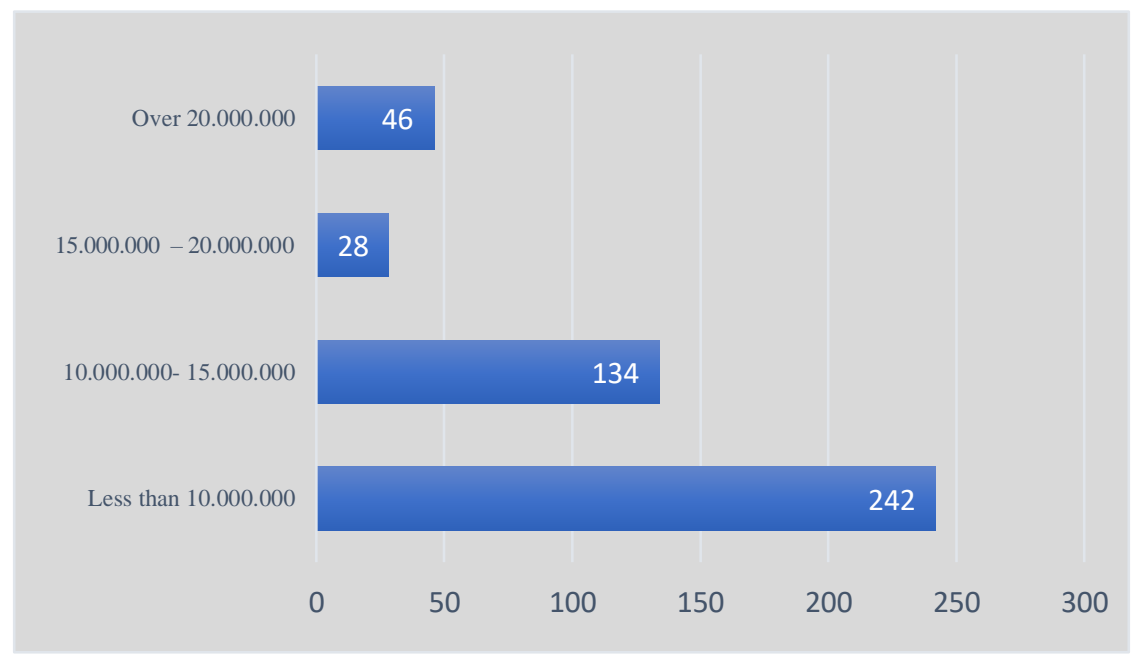

Figure 5. Monthly income

From the above figure of income data, most students have the monthly income of less than 10 million VND, with 242 students (53.8\%). The second group of monthly income ranges from 10-15 million VND with 134 students (29.8\%). 28 students (6.2\%) and 46 students (10.2\%) which have the monthly income of 15-20 million VND and over 20 million respectively.

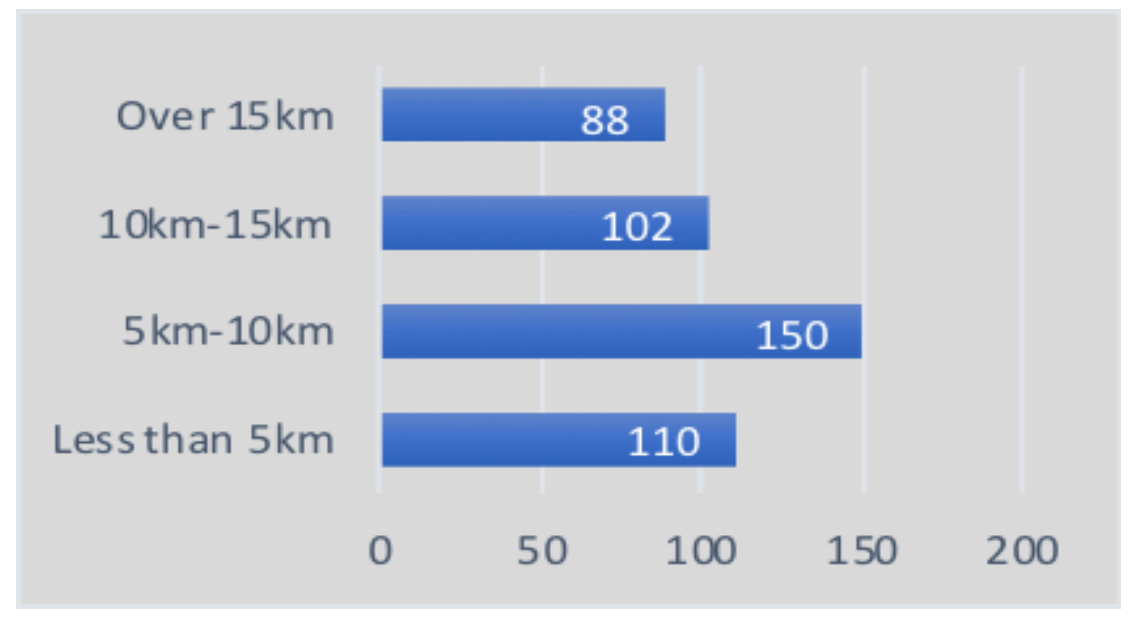

Figure 6. Location

Figure 6 shows the location - how far it is to the university from students' houses. Most students' houses are 5-10km away from the university, with 150 students (33.3\%). 110 students' houses $(24.4 \%)$ at a distance of less than $5 \mathrm{~km}$ to the university. Moreover, 102 students' houses $(22.7 \%)$ are $10-15 \mathrm{~km}$ away. 


\subsection{Factor analysis}

4.3.1. Exploratory Factor Analysis (EFA) for measurement scales of independent factors

The EFA uses the extraction method of principal component analysis with the rotation method of Varimax with Kaiser Normalization. Table 4 illustrates the KMO $=0.836$ which means that EFA is appropriate. The rotated component matrix in table 5 describes EFA result. However, there are 10 variables which are rejected because of low loading factor $(<0.5)$. These variables are: c5, c20, c21, c32, c35, c36, c37, c39, c43, c45.

\section{Table 4}

KMO and Bartlett's Test

\begin{tabular}{lrr}
\hline Kaiser-Meyer-Olkin Measure of Sampling Adequacy. & .836 \\
Bartlett's Test of Sphericity & Approx. Chi-Square & 13724.743 \\
& df & 595 \\
& Sig. & .000
\end{tabular}

Source: The researcher's data analysis

Table 5

EFA Result

\section{Component}

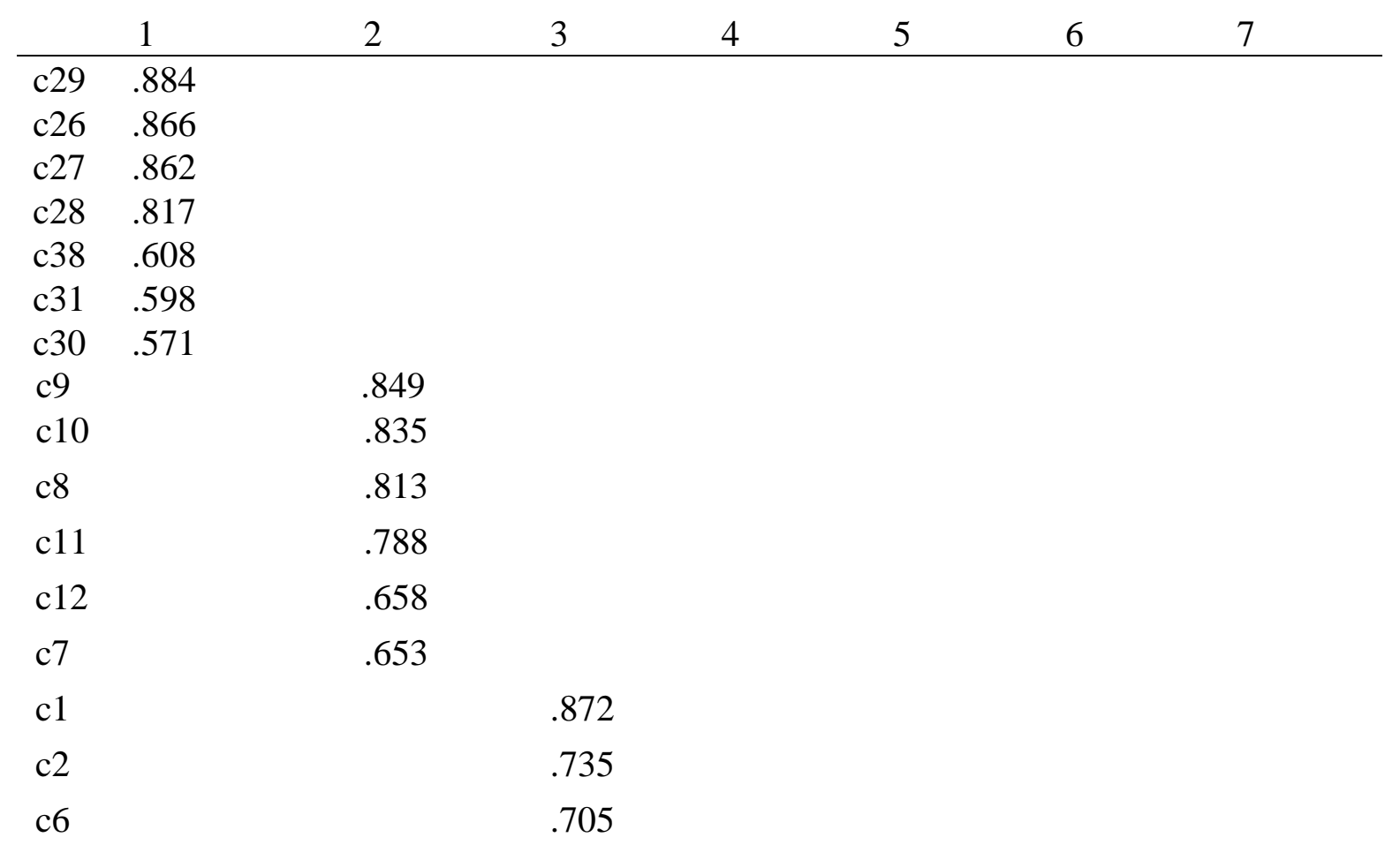




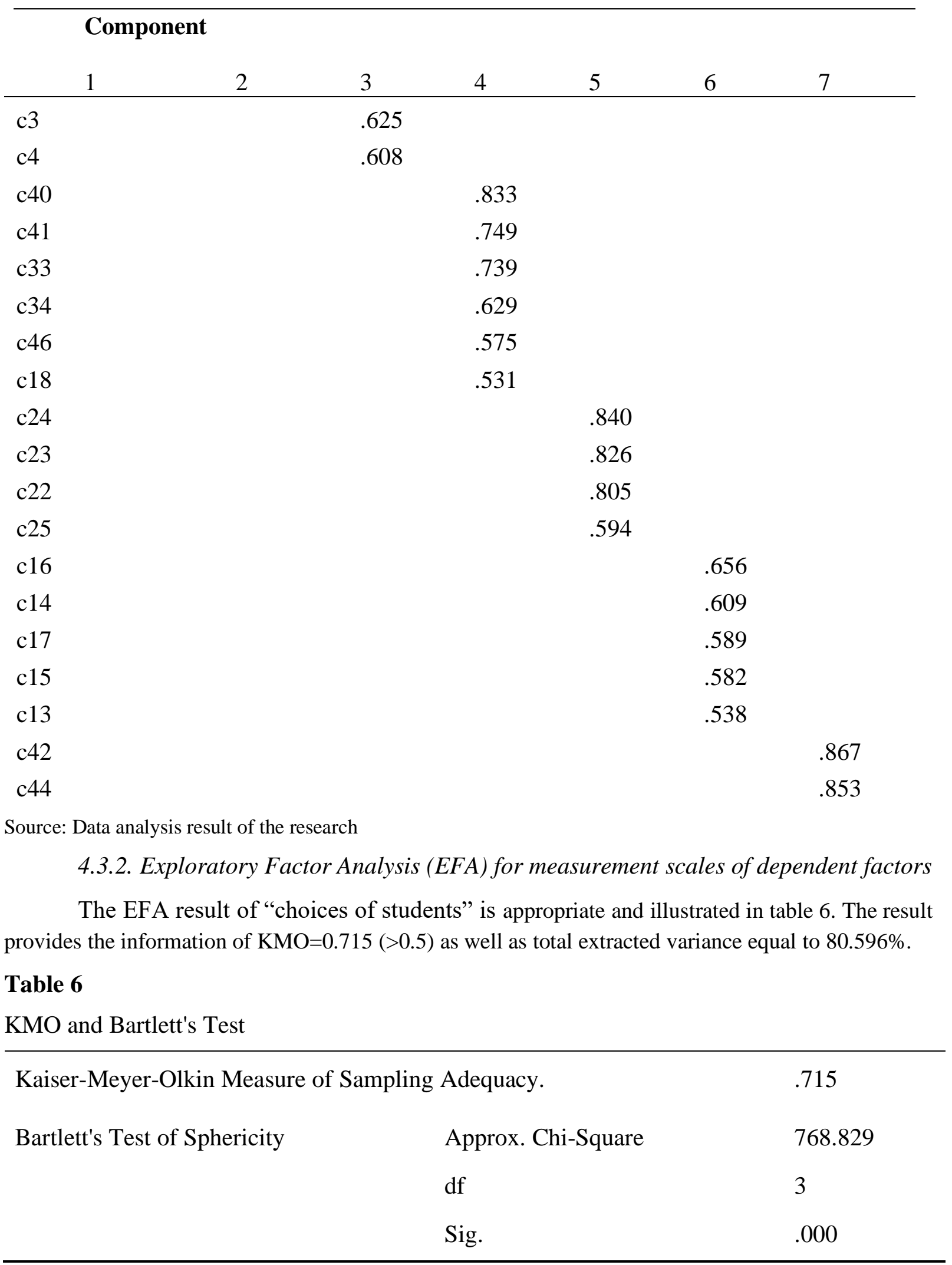

Source: The researcher's data analysis 


\subsection{Regression analysis}

Table 7 shows $\mathrm{R}$ square equal 0.687 which measures the proportion of the variation in the dependent variable. The $\mathrm{R}$ square is higher and appropriate for an explanation. Moreover, Durbin Watson which is 2.1 and we can predict that there is no autocorrelation between residuals. Thus, we do not reject the null hypothesis no autocorrelation, positive or negative. In other words, the regression assumption of no autocorrelation is respected. The significant in table 8 is less than 0.05 and this means the regression model use to predict dependent variables is appropriate. There is not much multicollinearity between independent variables. Table 9 shows that the tolerance of independent variables is greater than $0.1(>0.1)$ and VIF $<10$ (variance inflation factor). In table 9 the significance of variable "social responsibility" is 0.133 $(>0.05)$, thus there is not the impact of this variable on the dependent variable. Hence, the variable of "social responsibility" is rejected from the regression model.

\section{Table 7}

Model Summary

\begin{tabular}{llllcl}
\hline & & & Adjusted R & Std. Error of the & \\
Model & $\mathbf{R}$ & R Square & Square & Estimate & Durbin-Watson \\
\hline 1 & $.829^{\mathrm{a}}$ & .687 & .682 & .45991 & 2.100 \\
\hline
\end{tabular}

Source: The researcher's data analysis

\section{Table 8}

The analysis of variances

\begin{tabular}{lllllll}
\hline \multicolumn{2}{l}{ Model } & $\begin{array}{l}\text { Sum of } \\
\text { Squares }\end{array}$ & df & Mean Square & F & Sig. \\
\hline $1 \quad$ Regression & 205.533 & 7 & 29.362 & 138.815 & $.000^{\mathrm{b}}$ \\
& Residual & 93.491 & 442 & .212 & \\
& & & & & \\
& Total & 299.024 & 449 & & \\
\hline
\end{tabular}

Source: The researcher's data analysis 


\section{Table 9}

The regression result

\begin{tabular}{|c|c|c|c|c|c|c|c|}
\hline \multirow{3}{*}{$\begin{array}{l}\text { Model } \\
\text { (Constant) }\end{array}$} & \multicolumn{2}{|c|}{$\begin{array}{l}\text { Unstandardized } \\
\text { Coefficients } \\
\text { Std. }\end{array}$} & \multirow{2}{*}{$\begin{array}{c}\text { Standardized } \\
\text { Coefficients } \\
\text { Beta }\end{array}$} & \multirow[t]{2}{*}{$\mathbf{t}$} & \multirow{3}{*}{$\begin{array}{l}\text { Sig. } \\
.000\end{array}$} & \multicolumn{2}{|c|}{$\begin{array}{l}\text { Collinearity } \\
\text { Statistics }\end{array}$} \\
\hline & B & Error & & & & Tolerance & VIF \\
\hline & -.703 & .184 & & -3.831 & & & \\
\hline Cost & .314 & .037 & .276 & 8.559 & .000 & .681 & 1.469 \\
\hline Employee & -.119 & .038 & -.111 & -3.101 & .002 & .557 & 1.795 \\
\hline Lecturer Quality & .296 & .050 & .226 & 5.911 & .000 & .482 & 2.074 \\
\hline $\begin{array}{l}\text { Social } \\
\text { Responsibility }\end{array}$ & .054 & .036 & .054 & 1.505 & .133 & .541 & 1.847 \\
\hline Study Facilities & .187 & .036 & .174 & 5.220 & .000 & .637 & 1.571 \\
\hline Program Quality & .318 & .048 & .299 & 6.698 & .000 & .355 & 2.813 \\
\hline Reputation & .176 & .032 & .169 & 5.442 & .000 & .735 & 1.360 \\
\hline
\end{tabular}

Source: The researcher's data analysis

The result of regression can be shown as following:

Students' choices $=-0.703+0.276$ Cost -0.111 Employee +0.226 Lecturer Quality +0.174 Study Facilities + 0.299 Program Quality + 0.169 Reputation.

The regression result shows that the variables of cost, employee, lecturer quality, study facilities, program quality and reputation are these predicted variables for students 'choices. The most influenced factor is program quality with the beta of 0.299 . The next impacted factors are cost (beta $=0.276$ ), lecturer quality (beta $=0.226$ ), study facilities (beta $=0.174$ ) reputation (beta=0.169) and employee (beta=-0.111).

\subsection{Discussion}

Therefore, the factors of brand image which are recognized influence choices of students toward higher education institution. The most influenced factor is program quality with the beta of 0.299. The next impacted factors are cost (beta=0.276), lecturer quality (beta $=0.226$ ), study facilities (beta $=0.174$ ) reputation (beta=0.169) and employee (beta=-0.111). Thus, the hypotheses are accepted as follows:

H1: The human resources' competence is positive and direct to students' choices towards higher education institutions

There have been not only researches but also news supporting the evidence of the importance the human resources' competence. With the development of education in Vietnam, 
human resources' competence in general and performance lecturer's competence play essential roles at universities. Without no doubt, universities improve their ranking by performance lecturer's competence which provides animated and deep knowledge to students. Moreover, excellent professors may bring better researches to universities. The ranking of these universities will be improved accordingly. Understanding the crucial point of lecture quality, the universities have been taken into consideration and have the strategies to attract external professors and develop internal human resources. According to the survey, we can see that students concern this significant factor.

H2: The quality of the program is positive to students' choices towards higher education institutions

The reality which we cannot negate is that the higher a program quality is the higher the quality of students. Nowadays, universities pay attention to not only the lecturer quality but also the program quality. The survey shows that students have their concerns about the program quality. This factor directly affects their choices and their education quality.

H3: The infrastructure of the university is positive to students' choices towards higher education institutions

In reference to the survey, the next factor that the students considered is the infrastructure of the universities. It can be seen that the high quality of utilities and facilities will attract more students. The students may feel more satisfied with a range of support facilities such as library, conference hall, materials... for their education.

H4: The cost of the program is positive for students' choices towards higher education institutions

The survey shows that the cost of the program is a factor which students are interested in. It can be seen that the issue of financial problems is always taken into consideration.

H7: Reputation of the university is positive to students' choices towards higher education institutions

Reputation is a factor that students chose in this study. It reflexes that reputation contributes significantly to the brand images of the universities. The choices of students based on these brand images which are associated with the reputation of the universities.

The factors which are rejected due to EFA analysis:

H5: The innovation in management and training methods are not positive to students' choices toward higher education institutions

H6: Social responsibility of the university is not positive to students' choices towards higher education institutions

The reasons that the students do not consider innovation and social responsibilities are their concern and their knowledge. They do not concern these two factors because they do not 
affect their education according to their thoughts. Moreover, they might not know what these innovations and social responsibility activities are. Another reason can be come from universities. The universities may not have enough social activities to publish or a method of communication does not do well.

ANOVA is applied to test hypotheses about means of two or more groups of one independent variable (Pallant, 2007). In this study, types of jobs are considered to be the independent variable. Because in the test of homogeneity of variances, the sig is $0.018<0.05$, this means equal variances are not assumed. Thus, in Post hoc the testing does not use Least Significant Difference. In this study, we use Tamhane's T2 to compare the mean of groups. The results of the ANOVA show that a statistical value of sig (0.01) is less than 0.05 . It indicates that there are significant differences at the $p<0.05$ level in the mean scores for students' choices towards higher education institutions across the six types of job $[\mathrm{F}(5,444)=4.152, \mathrm{p}=0.001]$. According to ANOVA analysis, the hypothesis below is accepted:

H8c: Type of job influences students' choices toward higher education institutions

The student has the most impact on choices, which is the mean of 5. The next positions are lecturer, management, office staff, unemployment and self- employed in respectively.

ANOVA one way is used to test the relationship between students' choices and location, students' choices and monthly income. Because in the test of homogeneity of variances, the sig $=0.016<0.05$ and $0.000<0.05$ respectively (equal variances not assumed), thus in Post hoc the testing does not use Least Significant Difference. In this study, we use Tamhane's T2 to compare the mean of groups. In the ANOVA test, the sig is 0.388 and 0.224 respectively which is higher than 0.05 . Therefore, these following hypotheses below are not accepted:

H8a: Location influences students' choices towards higher education institutions

In Ho Chi Minh City, the location of the university is not much important for students' choices. It can be explained that the ability to go to work or education institutions around 10 kilometers is fine for people. Moreover, there are many other factors that need to pay attention to in reference to the choices of the students.

H8b: Income influences students' choices toward higher education institutions

The factor shows that most of the people in this survey have good financial situations for the choice of higher education.

\section{Conclusion}

The demand and concern about higher education institutions have been increased dramatically in Vietnam. Branding management is gaining importance since a university brand assists potential students in making right decisions and guarantees that their values and norms will match the institutional ones. By examining the factors of brand image in higher education which influence choices of students in three universities in Ho Chi Minh City, this paper provides further empirical evidence of brand image. Furthermore, the most factor affecting 
students 'choice would be defined and taken into consideration. This research also examines the influences of demographic variables such as location, monthly income and type of job to students' choices. Focus group and paper-based techniques are applied to build questionnaire forms. The surveys cover 450 samples which were collected by email survey technique. The technique of Cronbach's Alpha and Exploratory Factor Analysis are applied to test the reliability of all measurement scales. The next stage of analysis illustrates a regression between identified factors and the choice of students. The application of ANOVA is used for studying the relationship between demographic variables and students' choices. The results show that the positive significance of human resources' competence, program quality, infrastructure, cost and reputation of the universities to students' choices. Besides, there is a relationship between the type of job and the choices of students.

The recommendation can be the cost strategy with the competitive cost which provides for the students who need to be taken into consideration. The research on the costs of all universities across Vietnam may provide much useful information related to tuition fees for students. Moreover, the appropriate strategies which attract more excellent lecturers from not only local universities but also from international universities. With a good working environment and compensation, excellent lecturers may provide a long-term commitment to the development of such institutions. Besides, high-quality program can be improved by cooperation with reputation universities over the world. These Vietnamese institutions will have more benefits from co-operation in terms of program quality as well as Vietnamese lecturers' competence. An incentive money for research may attract more experienced researchers to come and contribute to the institutions. For the infrastructure, the demands for higher education in Vietnam have increased greatly so there is now intense competition between universities to attract students. The institutions need to develop themselves by investing money to improve infrastructure such as study facilities. The investment capital may come from many sources such as tuition fees, foreign investment, and corporations. With multimedia systems play a very important role in reputation improvement for the institutions.

Advertising through social networks, websites, blog communities and workshops is a popular tool to attract prospective students for applying to a university. The brand image cannot be built in the short-term. It needs long-term development with synchronization of all factors. Thus, the institutions need to pay attention to the importance of university reputation soon.

Besides the interview with students, managements or leaders of three institutions are interviewed to know about the factors of brand image toward higher education.

The collected information is very useful. All managements show that innovation in training is very important and they had strategies to develop the factors. Moreover, the social responsibility factors are not important enough but it may affect the reputation of these institutions. Thus, future research may concentrate on the gap between management and students toward brand image factor related to choices in a higher education institution. 


\section{References}

Aaker, D. A., \& Joachimsthaler, F. (2000). Brand leadership: Building assets in the information society. New York, NY: Free Press.

Ali, H. A., \& Si, M. (2015). Performance lecturer's competence as the quality assurance. The International Journal of Social Sciences, 30(1), 30-45.

Bhasin, H. (2013). What is brand image and its importance to an organization? Retrieved March 3, 2018, from Marketing91 website: https://www.marketing91.com/brand-loyalty/

Chapman, D. W. (1981). A model of student college choice. Journal of Higher Education, 52(5), 490-505.

College Board. (2005). The impact of demographic changes on higher education: Summary of conference. Washington, DC: College Board.

de Chernatony, L. (1999) Brand management through narrowing the gap between brand identity and brand reputation, Journal of Marketing Management, 15, 157-179. doi:10.1362/026725799784870432

Do, L. T. H., Nguyen, H. T. N., \& Nguyen, A. T. L. (2015). Factors influencing VNU-IS students' choice of university. Journal of Science, 31(4), 67-76.

Drori, G. S., Delmestri, G., \& Oberg, A. (2013). Branding the university: Relational strategy of identity construction in a competitive field. Portland Press Limited, Volume Compilation, 137-151.

Enache, I.-C. (2011). Marketing higher education using the 7 Ps framework. Transilvania University of Braşov, 4(53), 23-30.

Green, S. B. (1991). How many subjects does it take to do a regression analysis? Multivariate Behavior Research, 26(3), 499-510. doi:10.1207/s15327906mbr2603_7

Han, Y. (2006). Impact of brand identity on perceived brand image of the Nelson Mandela Metropolitan University. (Unpublished doctoral dissertation). Nelson Mandela Metropolitan University, Port Elizabeth.

Heding, T., Knudtzen, C. F., \& Bjerre, M. (2009). Brand management: Research, theory and practice. New York, NY: Routledge.

Kapferer, J.-N. (2012). The new strategic brand management: Advanced insights and strategic thinking (5th ed.). London, Philadelphia and New Delhi: UK, USA and India: Kogan Page.

Keller, K. L. (2013). Strategic brand management: Building, measuring, and managing brand equity (4th ed.). London, UK: Pearson Education Limited.

Kotler, P. (1997). Marketing management (7th ed.). Upper Saddle River, NJ: Prentice Hall.

Le, M. N. B. (2012). Solutions to improve image brand of Faculty of Business AdministrationSai Gon University. Retrieved March 8, 2018, from Saigon University website: https://sgu.edu.vn/?lang=en 
Martensen, A., \& Grønholdt, L. (2005). Reputation in higher education: Development, validation and application of a model. København, Danmarks: Copenhagen Business School.

MSG Management Study Guide. (n.d.). Retrieved May 9, 2018, from http://managementstudyguide.com/brand-positioning.htm

Nguyen, N., \& Leblanc, G. (2001) Corporate image and corporate reputation in customers' retention decisions in services. Journal of Retailing \& Consumer Services, 8(4), 227-236. doi:10.1016/S0969-6989(00)00029-1

Pallant, J. (2007). SPSS Survival manual (3rd ed.). New York, NY: McGraw Hill.

UNESCO. (1998). World declaration on higher education. Retrieved November 20, 2017, from http://www.unesco.org/education/educprog/wche/declaration_eng.htm

Wheeler, A. (2009). Designing brand identity (3rd ed.). Hoboken, NJ: John Wiley \& Sons.

Wiese, M., Heerden, C. H. V., \& Jordaan, Y. (2010). The role of demographics in students' selection of higher education institutions. Acta Commercii, 10(1), 150-163. doi:10.4102/ac.v10i1.124

Zhang, Y. (2015). The impact of brand image on consumer behavior: A literature review. Open Journal of Business and Management, 3(1), 58-62. doi:10.4236/ojbm.2015.31006 